\title{
New Objective Column
}

National Cancer Institute

\section{Source}

National Cancer Institute. New Objective Column. NCI Thesaurus. Code C161777.

A proprietary separation column manufactured by New Objective. 